(2) OPEN ACCESS

${ }^{1}$ Institute for Global Tobacco Control, Johns Hopkins University Bloomberg School of Public Health, Baltimore, Maryland, USA

${ }^{2}$ Health, Behavior and Society, Johns Hopkins University Bloomberg School of Public Health, Baltimore, Maryland, USA

Correspondence to Dr Joanna E Cohen, Institute for Global Tobacco Control, Johns Hopkins University Bloomberg School of Public Health, Baltimore, MD 21205, USA: jcohen@jhu.edu

Received 11 October 2019 Revised 23 March 2020 Accepted 16 April 2020

\title{
Global review of tobacco product flavour policies
}

\author{
Olufemi Erinoso 이, , Katherine Clegg Smith 지, ${ }^{2}$ Michael lacobelli, ${ }^{1}$ Sejal Saraf, \\ Kevin Welding 지, 'Joanna E Cohen
}

\begin{abstract}
Objective We determined which countries prohibit flavoured tobacco products and the details of those restrictions in order to identify possible gaps and opportunities for these and other countries to address. Methods We reviewed the grey literature, scanned news articles and consulted with key informants and identified 11 countries and the European Union (EU) that ban or restrict tobacco product flavours. We reviewed policy documents for their stated policy rationale, terms and definitions of flavours, tobacco products covered and restrictions on the use of flavour imagery and terms on tobacco product packaging.
\end{abstract}

Results Countries with a tobacco product flavour policy include the USA, Canada, Brazil, Ethiopia, Uganda, Senegal, Niger, Mauritania, EU (28 Member States), Moldova, Turkey and Singapore. Most of the countries' policies provide a rationale of dissuading youth from taking up tobacco use. Ten of the 12 policies use the terms 'flavours' $(n=6)$ or 'characterising flavours' $(n=4)$. Six policies cover all products made entirely or partly of tobacco leaf. Countries consistently prohibit flavours associated with fruits, vanilla and spices. The USA and Niger make an exception for menthol, while Mauritania and Uganda do not specify the scope of flavours or ingredients covered by their policies. Eight policies make no specific reference to restricting flavour descriptors on tobacco product packaging.

Conclusion Countries looking to implement policies restricting flavours in tobacco products can build on existing comprehensive policies. Future research could examine the implementation and impacts of these policies, to inform other countries interested in acting in this policy domain.

\section{INTRODUCTION}

Flavours shape perceptions of and experience with tobacco products, ${ }^{1}$ provide variety and diversity in the market, are often perceived as less harmful and impart a taste, aroma or sensation beyond that imparted by tobacco-flavoured products. ${ }^{1} 2$ Flavoured tobacco products increase appeal, which can promote the use of tobacco. ${ }^{1}$ One aim of the WHO Framework Convention on Tobacco Control (FCTC) is to reduce tobacco product appeal. ${ }^{3}$ The partial guidelines for implementation of articles 9 and 10 recommend the prohibition or restriction of flavoured tobacco products due to their effect in attracting adolescents and disguising the harshness of tobacco. ${ }^{4}$

Industry documents reveal that since at least the 1970s, tobacco companies have researched flavoured cigarettes. ${ }^{5}$ In the USA, it has been established that menthol cigarettes were marketed specifically to adolescents and racial minorities. ${ }^{6}$ Feirman et $a l^{2}$ reported the particular appeal of flavoured tobacco products to younger age groups, who begin with these products and progress to longterm tobacco use. ${ }^{7}$ Flavoured tobacco products are marketed around the world; for example, British American Tobacco (BAT) sold flavour variants in 116 countries in $2015 .^{8}$ Further, cigarettes with flavour capsules (capsules in filters that smokers can press to release a liquid that flavours smoke, hereafter referred to as 'capsules') have gained significant market share, with the leading markets for these products being in Latin America. ${ }^{9}$ Flavours in tobacco products can be predominantly from one compound (eg, menthol, clove and vanilla) and/or require the use of multiple compounds (eg, strawberry flavour is composed of 360 constituents). ${ }^{10}$

National and subnational (eg, state, province and municipality) jurisdictions have taken action to reduce the availability of flavoured tobacco products. No studies to date have examined the details of the tobacco flavour policies enacted by countries. In this paper, we identify the countries that passed tobacco flavour policies (sales restrictions, product standards or a combination of both) as of August 2019 and assess and compare the policy rationale, terms and concepts used to describe flavours, types of tobacco products and flavour constituents covered by the policy, restrictions on the mechanism for delivery of flavours (eg, capsules) and restrictions related to flavour imagery and descriptors on product packaging. Further, we identify policy gaps that might be exploited by the tobacco industry to continue to entice new users and minimise perceptions of product harm. These findings can inform other countries looking to enact tobacco product flavour policies.

\section{METHODS}

Identification of tobacco product flavour policies Countries that have national-level tobacco flavour policies as of August 2019 were identified using three sources: (1) search of the 2015 Tobacco Control Legal Consortium report on How Other Countries Regulate Flavored Tobacco Products; ${ }^{11}$ (2) communications with Campaign for TobaccoFree Kids' International Legal Consortium (ILC) ${ }^{12}$ and (3) search of news stories using 'Tobacco Watcher' (https://tobaccowatcher.globaltobaccocontrol.org/), an online tobacco media monitoring site. $^{13}$

Countries were included if they had enacted national or multinational regional tobacco product flavour policies. Policies were reviewed from government websites and the CTFK Tobacco Control Laws online database when we required an English translation. ${ }^{14}$ 


\section{Canada \\ - Non-menthol \\ flavors in \\ cigarettes, little \\ cigars, and blunt \\ wraps (2009) \\ - Non-menthol \\ flavors in cigars > \\ $1.4 \mathrm{~g}$ and $<6 \mathrm{~g}$ \\ (2015) \\ - Menthol cigarettes \\ (2017) \\ - Flavor illustrations \\ on vaping \\ products (2018) \\ United States \\ - Non-menthol \\ characterizing \\ flavors in \\ cigarettes \\ 2009}

\section{2} 2014

\author{
EU TPD \\ - All flavors in \\ cigarettes and \\ RYO tobacco \\ Singapore \\ - Fruit flavors in \\ waterpipe \\ products
}

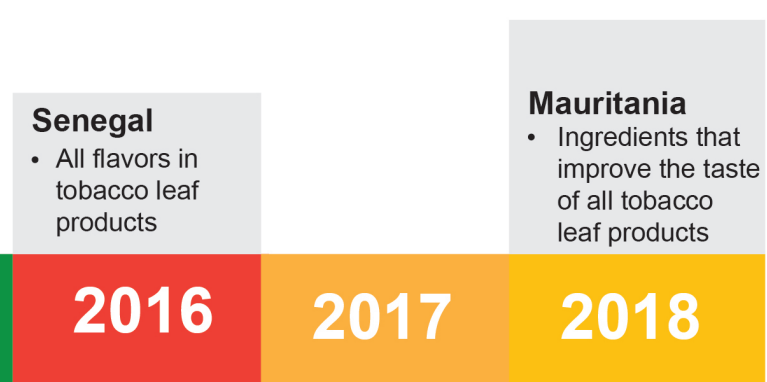

\section{Ethiopia}

- All flavors in tobacco leaf products

Moldova

- All flavors in cigarettes and RYO tobacco

\section{Uganda}

cigarettes and

RYO (2012)

- Menthol flavor in

cigarettes and

RYO tobacco

(2015)

- All flavors in

cigarettes and

RYO tobacco

(2019)
- All flavors in

tobacco leaf

products

Figure 1 Timeline for enactment of flavour policies by country and the EU. EU, European Union; RYO, roll-your-own; TPD, Tobacco Products Directive.

\section{Data extraction}

Descriptive information was extracted from policy documents representing 11 countries and the European Union's (EU) Tobacco Products Directive (TPD) relating to the following seven constructs: (1) policy rationale, (2) terms and definition of prohibited flavours, (3) tobacco products covered, (4) policy implementation status, (5) prohibition of flavour descriptors or imagery on packaging, (6) preemption status and (7) restrictions on mechanism of flavour delivery (eg, capsules).

\section{Data analysis}

The term 'countries' is used throughout to include the EU. Similarities and differences between policies were determined by assessing the extracted data across countries. Potential gaps were identified based on the comprehensiveness of the seven policy constructs recorded for each country.

\section{RESULTS}

\section{Overview}

We identified 12 eligible, currently active or pending policies (11 national policies and the EU TPD) pertaining to tobacco product flavours. The countries identified were the USA, ${ }^{15}$ Canada, ${ }^{16-18}$
Brazil, ${ }^{19}$ Ethiopia, ${ }^{14}{ }^{20}$ Uganda, ${ }^{21}$ Senegal, ${ }^{14}{ }^{22}$ Niger, ${ }^{14}{ }^{23}$ Mauri-

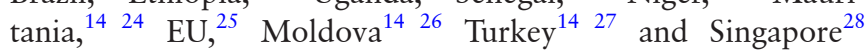
(figure 1).

As of September 2009, the USA prohibits cigarettes with characterising flavours (described further below) except for menthol under the authority of the Family Smoking Prevention and Tobacco Control Act (FSPTCA). In Canada, the Tobacco Act was amended in October 2009 to ban the sale of flavoured cigarettes, little cigars that weigh no more than $1.4 \mathrm{~g}$, and blunt wraps, with the exception of menthol. Amendments adopted in December 2015, October 2017 and November 2018 expanded the restrictions to include cigars weighing more than $1.4 \mathrm{~g}$ but less than $6 \mathrm{~g}$, include menthol cigarettes ${ }^{17}$ and prohibit illustrations of flavour on e-cigarette products, but not prohibit the sale of flavoured e-cigarettes themselves. ${ }^{18}$

In 2012, the Brazilian Health Regulatory Agency (ANVISA) passed a regulation (RDC 14/2012) that bans additives, including flavours, in tobacco products. Brazil's flavour policy is not in effect as it is being challenged by Sinditabaco and other industryrelated groups in Brazil. ${ }^{29}$

The Turkish Tobacco and Alcohol Market Regulation Agency issued regulations in 2012 (amended in 2015 to include menthol) 
prohibiting 43 ingredients in cigarettes and roll-your-own (RYO) tobacco. Additional regulations by the Ministry of Agriculture and Forestry were passed in 2019, prohibiting all scents and flavours in these products; these provisions go into effect in May 2020.

In May 2014, the EU TPD was enacted, which binds all 28 Member States to a prohibition on the sale of cigarettes and RYO tobacco with a characterising flavour, including menthol, if the union-wide sales volume for a particular product represents 3\% or more of that product category by 2020. (That is, if coffeeflavoured cigarettes represent at least 3\% of EU cigarette sales by volume, they would be prohibited.) The final date for transposition of the TPD into law in all 28 EU Member States was set at May 2016 for characterising flavours, while the menthol provisions go into effect in May 2020.

In November 2014, Singapore enacted the Tobacco (Control of Advertisements And Sale) Act prohibiting water pipe tobacco with fruit flavours and their policy is in effect. Three countries-Ethiopia, Moldova and Uganda-passed flavoured tobacco product restrictions in 2015 , followed by Senegal in 2017. Ethiopia's and Senegal's policies are in effect. Uganda was successful against a court challenge by British American Tobacco, Uganda (BATU) in May 2019, ${ }^{30}$ passing Tobacco Control Regulations in August 2019 with an expected implementation date of 1 February 2020. Moldova's policy goes into effect in May 2020. Niger and Mauritania enacted flavoured tobacco policy restrictions in 2017 and 2018, respectively, although their policies were not yet in effect as of January 2020. None of the policies we reviewed had clauses that preempt lower jurisdictions from enacting stronger policies, but neither did any include explicit antipreemption language.

\section{Provided rationale}

The policies in five countries (Ethiopia, Uganda, Senegal, Niger and Moldova) and the EU detailed an obligation to the WHO $\mathrm{FCTC}^{3}$ and the protection of public health as the rationale for prohibiting flavours. Six countries (USA, Canada, Ethiopia, Niger, Mauritania, Moldova) and the EU specified the protection of young people from the effects of tobacco as the rationale for their policies. For example, the Canadian Tobacco Act directly states, 'to protect young persons and others from inducements to use tobacco products and the consequent dependence on them'. ${ }^{16}$ Other rationales provided include protecting the environment, ${ }^{2021} 24$ the economy and facilitating trade within regional markets as seen in the EU TPD. ${ }^{25}$

\section{Terms}

Four terms were used to refer to flavours in the policies. These were: (1) 'characterising' or 'characteristic' flavour (USA, EU TPD, Moldova and Turkey); (2) 'flavour' (Canada, Brazil, Ethiopia, Uganda, Niger and Singapore); (3) 'characteristic aromatic agent' and 'aromatic agent' (Senegal) and (4) 'ingredients' (Mauritania) (table 1).

These four terms can be grouped broadly under two definitions. First, definitions that prohibit flavours with distinct/distinguishable/identifiable/noticeable properties (seven countries). Second, as seen in Brazil, Canada and Mauritania, definitions that prohibit additives or ingredients with flavour properties, which may not be noticeable or distinct but are able to impart and modify the flavour of tobacco products. Uganda and Singapore have no definition for the term 'flavour' used in the policy document containing their flavour bans.
The USA does not explicitly define 'characterising flavour'; however, it identifies flavours that are similar to the definitions used by countries that define the term 'characterising flavour,' in that they possess distinct or noticeable sensory effects in finished or unfinished tobacco products. Canada and Brazil use the term 'flavours' in reference to the prohibition of additives with flavouring properties in tobacco products, drawing from the Joint FAO/WHO Expert Committee on Food Additives (FAO JECFA) list for prohibited flavours. ${ }^{31}$ Mauritania uses the broad term 'ingredients' and specifies the prohibition to include ingredients that 'can improve the taste of tobacco products'; however, the policy does not specify the need for the flavours to possess distinct or noticeable perceptible sensory effects in tobacco products.

\section{Flavours banned, capsules and exemptions}

The USA and Niger prohibit all flavours except menthol in cigarettes. Canada prohibits menthol and other flavours, with the exception of cigars (without a cigarette filter, tipping paper and has a wrapper fitted in a spiral form) that weigh more than $1.4 \mathrm{~g}$ or $6 \mathrm{~g}$ or less; these products are allowed to have additives used to impart traditional alcohol flavours (eg, rum, whisky, wine, port). Brazil also prohibits menthol and other flavours. Both Canadian and Brazilian policies draw from, but are not limited to, the FAO JECFA. Brazil goes a step further by also referencing, although not limited to, 146 additives identified as flavours by the Flavor and Extract Manufacturers Association (FEMA). ${ }^{29} 3233$ Ethiopia, Senegal, Turkey, Moldova and the EU include menthol in their policies. Policies in Mauritania and Uganda do not specify the banned flavours, and there is no reference to menthol specifically, although Mauritania states that restrictions extend to ingredients that 'can improve the taste of tobacco products'. Singapore prohibits only fruit-flavours in waterpipe tobacco.

Flavours are prohibited in component parts of tobacco products such as papers and filters in the USA, Canada, the EU, Moldova, Turkey and Mauritania; further, the EU, Moldova and Turkey specifically prohibit flavours in capsules as mechanisms of flavour delivery.

\section{Tobacco products covered}

The tobacco products covered by the flavour bans vary, with most policies covering all products made entirely or partly of tobacco leaf. The USA, EU, Moldova and Turkey prohibit flavours in cigarettes and RYO products only. The EU prohibits additives in e-cigarette liquids that suggest a health benefit (eg, vitamins, caffeine or stimulants). In Canada, the prohibition of non-menthol flavours covers cigarettes, cigars (less than $6 \mathrm{~g}$ ), little cigars (less than $1.4 \mathrm{~g}$ ) and blunt wraps; menthol flavours are prohibited in all tobacco products. Brazil, Ethiopia, Mauritania, Niger, Senegal and Uganda restrict flavours in products manufactured or derived partly or entirely from tobacco leaf. Singapore prohibits fruit-flavours only in waterpipe products.

\section{Ban on flavour descriptors and images on tobacco packaging}

Canada prohibits flavour descriptors and imagery on tobacco and e-cigarette packaging stating: 'No one shall promote ... by means of the packaging, through an indication or illustration, including a brand element, that could cause a person to believe that the product has a flavour'. ${ }^{18}$ The EU TPD prohibits characterising flavour elements in text, signs or symbols on packaging as well as terms that state no flavouring. Moldova has a similar policy which prohibits text or image illustrations of flavours on tobacco product packaging; and Turkey prohibits 
Table 1 Flavour terms, definitions, rationale, tobacco products covered and implementation status, by country

\begin{tabular}{|c|c|c|c|c|c|}
\hline Country & Term & Definition and prohibited flavours & Rationale & Tobacco products & $\begin{array}{l}\text { Implementation } \\
\text { status (as of } \\
\text { August 2019) }\end{array}$ \\
\hline$U_{S A}^{15}$ & $\begin{array}{l}\text { Characterising } \\
\text { flavour }\end{array}$ & $\begin{array}{l}\text { The Act prohibits any 'constituent (including a smoke constituent) or } \\
\text { additive, an artificial or natural flavor (other than tobacco or menthol) } \\
\text { or an herb or spice, including strawberry, grape, orange, clove, } \\
\text { cinnamon, pineapple, vanilla, coconut, licorice, cocoa, chocolate, cherry, } \\
\text { or coffee, that is a characterizing flavor of the tobacco product or } \\
\text { tobacco smoke.' }\end{array}$ & $\begin{array}{l}\text { Protection of young } \\
\text { persons }\end{array}$ & $\begin{array}{l}\text { Cigarettes, roll-your- } \\
\text { own tobacco }\end{array}$ & In effect \\
\hline Brazil $^{19}$ & Flavour & $\begin{array}{l}\text { 'It is prohibited to import or sell in Brazil tobacco products that contain } \\
\text { any of the following additives: I- synthetic and natural substances } \\
\text { in any form (pure substances, extracts, oils, distillates, balms, among } \\
\text { others), with flavoring properties that can impart, intensify, modify } \\
\text { or enhance the flavor of the product, including additives identified } \\
\text { as flavoring agents: a) by the Joint FAO/WHO Expert Committee on } \\
\text { Food Additives - JECFA; or b) by the Flavor and Extract Manufacturers } \\
\text { Association - FEMA ... VI - fruits, vegetables or any product originating } \\
\text { from the processing of fruits and vegetables, except activated charcoal } \\
\text { and amides; VII - sweeteners, honey, molasses or any other substance } \\
\text { that can impart a sweet flavor, apart from sugars; VIII - seasonings, } \\
\text { herbs and spices or any substance that can impart a flavor of } \\
\text { seasonings, herbs and spices' }\end{array}$ & $\begin{array}{l}\text { No rationale } \\
\text { statement }\end{array}$ & $\begin{array}{l}\text { 'Tobacco products } \\
\text { containing partially } \\
\text { or wholly in its } \\
\text { composition tobacco } \\
\text { leaf.' (Definition as } \\
\text { stated in the policy } \\
\text { does not explicitly } \\
\text { include or exclude } \\
\text { products such as } \\
\text { electronic cigarettes) }\end{array}$ & Under litigation* \\
\hline Uganda $^{21}$ & Flavour & No definition & $\begin{array}{l}\text { Protection of public } \\
\text { health } \\
\text { Protection of the } \\
\text { environment } \\
\text { Obligation to WHO } \\
\text { FCTC }\end{array}$ & $\begin{array}{l}\text { 'Tobacco products } \\
\text { containing partially } \\
\text { or wholly in its } \\
\text { composition tobacco } \\
\text { leaf.' (Definition as } \\
\text { stated in the policy } \\
\text { does not explicitly } \\
\text { include or exclude } \\
\text { products such as } \\
\text { electronic cigarettes) }\end{array}$ & In effect \\
\hline Senegal ${ }^{22}$ & $\begin{array}{l}\text { Characteristic } \\
\text { aromatic agent } \\
\text { Aromatic agent }\end{array}$ & $\begin{array}{l}\text { 'a taste or scent, other than that of the tobacco, coming from an } \\
\text { additive or a combination of natural or artificial additives, particularly } \\
\text { those derived from fruits, spices, aromatic plants, alcohol, sweetening } \\
\text { elements, menthol, chocolate or vanilla, and which is identifiable prior } \\
\text { to or during the consumption of the tobacco product' } \\
\text { 'an additive that confers, modifies or improves a flavor or scent, by } \\
\text { itself or in conjunction with other ingredients' }\end{array}$ & $\begin{array}{l}\text { Protection of public } \\
\text { health } \\
\text { Obligation to WHO } \\
\text { FCTC }\end{array}$ & $\begin{array}{l}\text { 'Tobacco products } \\
\text { containing partially } \\
\text { or wholly in its } \\
\text { composition tobacco } \\
\text { leaf.' (Definition as } \\
\text { stated in the policy } \\
\text { does not explicitly } \\
\text { include or exclude } \\
\text { products such as } \\
\text { electronic cigarettes) }\end{array}$ & In effect \\
\hline
\end{tabular}


Table 1 Continued

\begin{tabular}{|c|c|c|c|c|c|}
\hline Country & Term & Definition and prohibited flavours & Rationale & Tobacco products & $\begin{array}{l}\text { Implementation } \\
\text { status (as of } \\
\text { August 2019) }\end{array}$ \\
\hline Niger $^{23}$ & Flavour & $\begin{array}{l}\text { 'a taste or smell, other than that of tobacco, derived from an additive } \\
\text { or combination of natural or artificial additives, especially fruit, spices, } \\
\text { herbs, alcohol, confectionery, chocolate or vanilla; identifiable before } \\
\text { or during the consumption of a tobacco product with the exception of } \\
\text { menthol.' }\end{array}$ & $\begin{array}{l}\text { Protection of young } \\
\text { persons and women. } \\
\text { Obligation to WHO } \\
\text { FCTC }\end{array}$ & $\begin{array}{l}\text { 'Tobacco products } \\
\text { containing partially } \\
\text { or wholly in its } \\
\text { composition tobacco } \\
\text { leaf.' (Definition, as } \\
\text { stated in the policy, } \\
\text { does not explicitly } \\
\text { include or exclude } \\
\text { products such as } \\
\text { electronic cigarettes) }\end{array}$ & Not in effect. \\
\hline Mauritania $^{24}$ & Ingredients & $\begin{array}{l}\text { 'any substance other than the leaves and other natural or } \\
\text { untransformed or unprocessed parts of the tobacco plant used in the } \\
\text { manufacture or preparation of a tobacco product and still present in } \\
\text { the finished product, even in modified form, including the paper, filter, } \\
\text { inks and glues' }\end{array}$ & $\begin{array}{l}\text { Protection of young } \\
\text { persons } \\
\text { Protection of public } \\
\text { health } \\
\text { Protection of the } \\
\text { environment }\end{array}$ & $\begin{array}{l}\text { 'Tobacco products } \\
\text { containing partially } \\
\text { or wholly in its } \\
\text { composition tobacco } \\
\text { leaf.' (Definition as } \\
\text { stated in the policy } \\
\text { does not explicitly } \\
\text { include or exclude } \\
\text { products such as } \\
\text { electronic cigarettes) }\end{array}$ & $\begin{array}{l}\text { Not in effect. } \\
\text { Legislative provision } \\
\text { to be ratified by a } \\
\text { Decree }\end{array}$ \\
\hline EU TPD ${ }^{25}$ & $\begin{array}{l}\text { Characterising } \\
\text { flavour }\end{array}$ & $\begin{array}{l}\text { 'characterising flavor means a clearly noticeable smell or taste other } \\
\text { than one of tobacco, resulting from an additive or a combination } \\
\text { of additives, including, but not limited to, fruit, spice, herbs, alcohol, } \\
\text { candy, menthol or vanilla, which is noticeable before or during the } \\
\text { consumption of the tobacco product' }\end{array}$ & $\begin{array}{l}\text { Protection of young } \\
\text { persons } \\
\text { Protection of public } \\
\text { health } \\
\text { To facilitate the } \\
\text { smooth functioning } \\
\text { of the internal } \\
\text { market for tobacco } \\
\text { and related products } \\
\text { Obligation to WHO } \\
\text { FCTC }\end{array}$ & $\begin{array}{l}\text { Cigarettes (including } \\
\text { capsules) and roll- } \\
\text { your-own tobacco }\end{array}$ & $\begin{array}{l}\text { Comes into full } \\
\text { effect on May } 2020\end{array}$ \\
\hline Moldova $^{26}$ & $\begin{array}{l}\text { Characteristic } \\
\text { flavour }\end{array}$ & $\begin{array}{l}\text { 'a clearly noticeable smell or taste other than one of tobacco, resulting } \\
\text { from an additive or a combination of additives, including, but not } \\
\text { limited to, fruit, spice, herbs, alcohol, candy, menthol or vanilla, which is } \\
\text { noticeable before or during the consumption of the tobacco product.' }\end{array}$ & $\begin{array}{l}\text { Protection of young } \\
\text { persons } \\
\text { Obligation to WHO } \\
\text { FCTC }\end{array}$ & $\begin{array}{l}\text { Cigarettes (including } \\
\text { capsules) and roll- } \\
\text { your-own tobacco }\end{array}$ & $\begin{array}{l}\text { Comes into effect on } \\
\text { May } 2020\end{array}$ \\
\hline Turkey $^{27}$ & $\begin{array}{l}\text { Characteristic } \\
\text { flavour }\end{array}$ & $\begin{array}{l}\text { 'The scent or flavor noticed before or during the use of tobacco } \\
\text { products that can be distinguished from the tobacco's own flavor } \\
\text { originating from an additive such as but not limited to fruit, spices, } \\
\text { herbs, alcohol, sugar, menthol or vanilla' }\end{array}$ & $\begin{array}{l}\text { Protection of public } \\
\text { health } \\
\text { In compliance with } \\
\text { EU TPD }\end{array}$ & $\begin{array}{l}\text { Cigarettes (including } \\
\text { capsules) and rolling } \\
\text { tobacco }\end{array}$ & $\begin{array}{l}\text { Comes into full } \\
\text { effect on May } 2020\end{array}$ \\
\hline Singapore $^{28}$ & 'Flavour' & $\begin{array}{l}\text { No explicit definition for flavours. Policy applies to } \\
\text { 'aromatic oils, aromatic extracts, molasses or sugar, ... [or] flavored } \\
\text { with fruit.' }\end{array}$ & $\begin{array}{l}\text { No rationale } \\
\text { statement }\end{array}$ & Water-pipe tobacco & In effect \\
\hline
\end{tabular}

Canada: The Joint FAO/WHO Expert Committee on Food Additives (JECFA) and Flavour and Extract Manufacturers Association (FEMA) Expert Panel in its lists of GRAS (Generally Recognised as Safe) flavouring substances referred to as 'GRAS 3' to 'GRAS 24'. In Canada, for cigars that weigh more than $1.4 \mathrm{~g}$ or $6 \mathrm{~g}$ or less (not including the 'weight of any mouthpiece or tip') rum, whisky, wine and port flavours are allowed (as long as the cigar does not have a cigarette filter, a tipping paper and has a wrapper fitted in spiral form); also, in cigars that weigh $>6 \mathrm{~g}$, there are no flavour restrictions (as long as the cigar does not have a cigarette filter, a tipping paper and has a wrapper fitted in spiral form). ${ }^{15} 16$ The order amending the schedule to the Tobacco Act (Menthol) ${ }^{16}$ removes menthol from the list of excluded additives, and by effect, menthol is added to the list of banned flavours.

${ }^{*}$ Brazil: ANVISA resolution no. $142012 .^{17}$

FCTC, Framework Convention on Tobacco Control; TPD, Tobacco Products Directive.

a 'distinguishing mark ... that refers to taste, scent, any flavor additive or other additive substances or absence thereof'. In the USA, Brazil, Ethiopia, Uganda, Senegal, Niger and Mauritania, there is no specific prohibition of 'flavour' descriptors on tobacco product packaging, but this may be implied given the prohibition of flavour ingredients. The Singaporean policy makes no reference to packaging.

\section{DISCUSSION}

This is the first global review of national policies restricting flavours in tobacco products. Eleven countries and the $28 \mathrm{EU}$ Member States restrict flavours in some tobacco products. Similarities exist in the rationale for policy, with the protection of children and public health commonly cited. The most common tobacco products covered by existing flavour policies are cigarettes, with only the EU regulating a small portion of e-cigarette liquid flavours. The EU, Moldova and Turkey specifically prohibit flavours in cigarette capsules. Menthol is included in the flavour ban policies of eight countries and the EU. Six countries explicitly prohibit the use of flavour terms or imagery on tobacco product packaging; none of these countries explicitly prohibit flavours in e-cigarettes.

The definition of flavour varies across policies restricting flavoured tobacco products. Some definitions are based on the presence of distinct or noticeable sensory effects (taste and aroma); others refer to additive agents or ingredients, without 
reference to a requirement for noticeable or distinct characteristics in taste or aroma. The term 'characterising flavour' as used by the USA, EU, Moldova and Turkey begs the question as to what constitutes a characterising versus a non-characterising flavour. In the USA, the use of the term 'characterising flavour' lacks a specific definition, raising questions about whether a flavour with a noticeable sensory impression but not identifiable as a specific flavour, would be covered. The EU, Moldova and Turkey use the same term, but define 'characterising flavours' as having a 'clearly noticeable smell/scent ... other than tobacco.'

Prohibitions based solely on prohibited additive or ingredient compounds may be challenging for enforcement, ${ }^{34}$ especially in low-income and middle-income countries without sophisticated lab facilities and expertise, as complex flavours such as cherry and strawberry are produced through the use of hundreds of constituents. ${ }^{10}$ Throughout the world, tobacco companies have introduced 'concept flavours'- tobacco products with packaging that includes a descriptor that does not directly name a fruit, food, beverage or spice, but that denotes a taste, aroma or sensation other than tobacco-flavoured-such as 'Ibiza Sunset', 'Velvet Fusion Blast', and 'Crystal Blue'; it is ambiguous as to what these might taste or smell like. Concept flavours have been found on packaging of cigarettes, smokeless tobacco, little cigars and e-cigarettes.

The presence of flavour terms and images on tobacco product packaging can potentially contribute to the appeal of tobacco products, ${ }^{35}$ which in turn can influence use. ${ }^{3637}$ Restricting the use of images, colours and text that connote flavours and potentially mislead consumers can minimise loopholes that may be exploited by the tobacco industry. Restrictions should be inclusive of flavour capsules and images of capsules that can communicate less harm to users, especially adolescents and youth. ${ }^{3637}$

Tobacco industry internal documents reveal how tobacco companies manipulated pack colours and designs to influence the perception of flavours and taste of tobacco products and potentially encourage uptake of smoking. ${ }^{38}$ Flavoured tobacco policy restrictions should address the product, its packaging and marketing to be maximally effective at reducing appeal. Although we did not include Thailand and South Korea in this review because they do not have policies to restrict flavours, it is noteworthy that they do not allow flavouring terms and images on packaging. Canada does not allow flavouring terms and images on e-cigarette packaging.

We recommend prohibiting the sale and marketing of flavours across all tobacco products to minimise the possibility of consumers substituting one product for another and to prohibit manufacturers exploiting gaps in a partial flavour ban. ${ }^{39}$ Switching between tobacco products was seen with adolescents in the USA shortly after the ban of flavours in cigarettes. ${ }^{40}$ Limiting the scope of a policy with respect to the tobacco products covered, such as exclusion of waterpipe tobacco and cigars, may present opportunities for the industry to market flavoured variants of the exempted products, and lure users to switch to these exempted products. Following the tobacco ban in the USA, Djarum maintained the same filter and tobacco formulation for its clove cigarettes and simply changed the wrapper, thereby changing its qualification from a cigarette to a cigar; this move effectively circumvented the cigarette flavour ban. ${ }^{41}$

The methodology used in this policy review has some limitations. Although a comprehensive review of policy data bases was undertaken, relevant documents using different search terms or languages may have been missed. Also, we reviewed enacted national-level flavour policies; it is important to note that subnational jurisdictions including states, provinces and cities have implemented a range of flavour restrictions that are beyond the scope of this review, and there is likely a lot to learn from that accumulated experience. Future research could examine the implementation of these policies, and any actions tobacco companies are taking to undermine them, to make recommendations to other countries interested in acting in this policy domain.

Comprehensive policy restrictions on the sale and marketing of flavoured tobacco products should be inclusive of: menthol flavours; tobacco products made partly or completely of tobacco leaf, as seen in Brazil, Ethiopia, Uganda, Senegal, Niger and Mauritania; a definition of flavours that incorporates both characterising and concept flavours and flavour capsules and the prohibition of flavour terms or images on tobacco packaging as well as marketing materials. Policies should be structured in a manner that governments are not put in a position to prove that a sensation, taste or aroma other than tobacco-flavoured is characterising (that is, that it can be named as a known food or flavour). As long as the sensation, taste or aroma is distinguishable (perceived by the sense of taste or smell) as being something other than tobacco-flavoured that should be sufficient. National and regional policies should not include preemption clauses and should include explicit anti-preemption language to unequivocally authorise states, provinces and localities to enact stronger restrictions than those nationally. Eliminating flavoured tobacco products has the potential to reduce the appeal, initiation and continued use of tobacco products and the subsequent harms that result from their use. ${ }^{142}$ This may also prevent consumers from being misled about the relative harm of flavoured tobacco products.

Countries considering to adopt and implement flavoured tobacco policies can learn from and build on the strengths and challenges posed by existing policies. Policies prohibiting the sale of flavoured tobacco products across a broad range of products as well as restrictions on flavour descriptors (text and images) on packaging, will serve to complement other efforts to reduce the appeal of tobacco products.

\section{What this paper adds}

- Bans or restrictions on flavours in tobacco products have the potential to reduce the appeal and use of tobacco products. As of 2019, 11 countries and the European Union have enacted legal restrictions on the sale of flavoured tobacco products. We explored the similarities and differences between these policies.

- Similarities include aspects of the policy rationale and terms used. Differences include tobacco products covered, whether menthol is prohibited and having explicit restrictions on the use of flavour descriptors and images on tobacco packaging.

- Existing policies could be strengthened by prohibiting all flavours -including menthol and 'concept' flavours (products with names that do not explicitly identify a flavour such as 'Purple Blast' or 'Ibiza Sunset') — as well as having explicit restrictions on descriptors, images and colouring on packaging that may be perceived as a flavour, sensation, taste or aroma.

Acknowledgements We would like to thank Kaitlin Donley and Liz Candler of the International Legal Consortium at the Campaign for Tobacco-Free Kids; Rob Cunningham at the Canadian Cancer Society who provided a legislative overview of flavour policy amendments in Canada and Nasozi Kakembo at the Institute for Global Tobacco Control who contributed to the design of the figure illustrating the 
enactment of the reviewed policies. We also thank the reviewers who provided detailed and constructive feedback.

Contributors OE drafted the article. ML, SS, KCS and JEC edited and provided feedback on the article. All authors approved the final draft.

Funding This work was supported with funds from the Bloomberg Initiative to Reduce Tobacco Use.

\section{Competing interests None declared.}

Patient consent for publication Not required.

Provenance and peer review Not commissioned; externally peer reviewed.

Data availability statement Data are publicly available. The data for this paper were from country laws, which we cite in the paper. We provide citations for, and links to, the relevant laws.

Open access This is an open access article distributed in accordance with the Creative Commons Attribution Non Commercial (CC BY-NC 4.0) license, which permits others to distribute, remix, adapt, build upon this work non-commercially, and license their derivative works on different terms, provided the original work is properly cited, appropriate credit is given, any changes made indicated, and the use is non-commercial. See: http://creativecommons.org/licenses/by-nc/4.0/.

\section{ORCID iDs}

Olufemi Erinoso http://orcid.org/0000-0003-0733-3847

Katherine Clegg Smith http://orcid.org/0000-0003-2140-1690

Kevin Welding http://orcid.org/0000-0002-1833-6691

Joanna E Cohen http://orcid.org/0000-0002-3869-3637

\section{REFERENCES}

1 Huang L-L, Baker HM, Meernik C, et al. Impact of non-menthol flavours in tobacco products on perceptions and use among youth, young adults and adults: a systematic review. Tob Control 2017;26:709-19.

2 Feirman SP, Lock D, Cohen JE, et al. Flavored tobacco products in the United States: a systematic review assessing use and attitudes. Nicotine Tob Res 2016;18:739-49.

3 World Health Organization (WHO). Framework Convention on Tobacco Control. the United nations Treaty collection, 2005. Available: https:/treaties.un.org/pages/ ViewDetails.aspx? src=TREATY\&mtdsg_no=IX-4\&chapter=9\&clang=_en [Accessed 18 Feb 2019].

4 World Health Organization (WHO). Partial guidelines for implementation of articles 9 and 10, 2017. Available: http://www.who.int/fctc/treaty_instruments/guidelines articles_9_10_2017_english.pdf [Accessed 18 Feb 2019].

5 Carpenter CM, Wayne GF, Pauly JL, et al. New cigarette brands with flavors that appeal to youth: tobacco marketing strategies. Health Aff 2005;24:1601-10.

6 Richardson A, Ganz O, Pearson J, et al. How the industry is marketing menthol cigarettes: the audience, the message and the medium. Tob Control 2015;24:594-600.

7 Ashare RL, Hawk LW, Cummings KM, et al. Smoking expectancies for flavored and non-flavored cigarettes among college students. Addict Behav 2007;32:1252-61.

8 Gray A. Investor day 2015. marketing strategy, 2015. Available: http://www.bat.com/ group/sites/UK__9ZTFCM.nsf/vwPagesWebLive/DOA26JV7/\$FILE/04_Marketing_ Strategy.pdf?openelement [Accessed 06 May 2019].

9 Thrasher JF, Islam F, Barnoya J, et al. Market share for flavour capsule cigarettes is quickly growing, especially in Latin America. Tob Control 2017;26:468-70.

10 Paschke M, Hutzler C, Henkler F, et al. Toward the stereochemical identification of prohibited characterizing flavors in tobacco products: the case of strawberry flavor. Arch Toxicol 2015;89:1241-55.

11 Tobacco Control Legal Consortium. How other countries regulate flavored tobacco products, 2015. Available: https://www. publichealthlawcenter.org/sites/default/files/ resources/tclc-fs-global-flavored-regs-2015.pdf [Accessed 06 May 2019].

12 International Legal Consortium. Global legal center. Available: https://www. tobaccofreekids.org/what-we-do/global/legal [Accessed 25 Feb 2019].

13 Tobacco Watcher. Real time artificial Intelligencefor tobacco control. Available: https:// tobaccowatcher.globaltobaccocontrol.org/ [Accessed 06 May 2019].

14 Campaign for Tobacco-Free Kids. Tobacco control laws. legislation, 2019. Available: https://www.tobaccocontrollaws.org/legislation [Accessed 25 Feb 2019].

15 U.S FDA. Family Smoking Prevention and Tobacco Control Act Chapter IX of the FDCA - Tobacco Products, 2009. Available: https://www.fda.gov/TobaccoProducts/Labeling/ RulesRegulationsGuidance/ucm263053.htm [Accessed 25 Feb 2019].

16 Parliament of Canada. Bill C-32 an act to amend the Tobacco Act, chapter 27 of the statutes of Canada, 2009. Available: http://www.parl.ca/DocumentViewer/en/40-2/ bill/C-32/royal-assent [Accessed 25 Feb 2019].

17 Government of Canada. Order amending the schedule to the Tobacco Act (menthol) Canada Gazette. Available: http://www.gazette.gc.ca/rp-pr/p2/2017/2017-04-05/ html/sor-dors45-eng.html [Accessed 15 Aug 2019]

18 Government of Canada. Tobacco and Vaping Products Act, 2018. Available: https:// laws-lois.justice.gc.ca/eng/acts/T-11.5/page-1.html\#h-1 [Accessed 07 Mar 2019].
19 Agência Nacional De Vigilância Sanitária (ANVISA - National Health Surveillance Agency). Collegiate Directorate Resolution- RDC N 14. Diário Oficial da União Section 1 - No 53. Available: http://portal.anvisa.gov.br/documents/10181/2978962/ RDC 14 2012 .pdf/baeb28a7-90fc-49f3-9bf8-761de80af0b7 [Accessed 25 Feb 2019].

20 Tobacco Control Directive. No 28/2015. Ethiopian food, medicine and healthcare administration and control authority, 2015. Available: https:/www. tobaccocontrollaws.org/legislation/country/ethiopia/laws [Accessed 07 Mar 2019].

21 Uganda Legal Information. The Tobacco Act, 2015. Available: https://ulii.org/ug/ legislation/act/2015/22-3 [Accessed 25 Feb 2019].

22 Republic of Senegal Decree. No. 2016- 1008 concerning the implementation of law No. 2014-14 manufacture, packaging, labeling, sale and use of tobacco. Available: https://www.tobaccocontrollaws.org/legislation/country/senegal/laws [Accessed 07 Mar 2019].

23 Republic of Niger Decree. Prohibiting the import, distribution and tobacco products containing flavors. Available: https://www.tobaccocontrollaws.org/legislation/country/ niger/laws [Accessed 07 Mar 2019].

24 Islamic Republic of Mauritania. Law No. 2018-020 concerning the production, importation, distribution, sale, advertising, promotion and tobacco consumption and its products, 2018. Available: https://www.tobaccocontrollaws.org/legislation/country/ mauritania/laws [Accessed 07 Mar 2019].

25 European Union Law. Directive 2014/40/EU of the European Parliament and of the Council of 3 April 2014 on the approximation of the laws, regulations and administrative provisions of the member states concerning the manufacture, presentation, and sale of tobacco and related products and Repealing Directive 2001/37/EC, 2014. Available: https://eur-lex.europa.eu/legal-content/EN/TXT/?qid= 1399478051133\&uri=0J:JOL_2014_127_R_0001 [Accessed 07 Mar 2019].

26 Campaign for Tobacco-Free Kids. Law no 278-XVI 2007, on tobacco and tobacco articles (official Gazette of the Republic of Moldova, 2008, no. 47-48, art. 139), 2015 Available: https://www.tobaccocontrollaws.org/legislation/country/moldova/laws [Accessed 07 Mar 2019].

27 Campaign for Tobacco-Free Kids. Regulation on the procedures and principles related to the production methods, labeling and surveillance of tobacco products, 2015. Available: https://www.tobaccocontrollaws.org/legislation/country/turkey/laws [Accessed 07 Mar 2019].

28 Ministry of Health, Singapore. Tobacco (control of advertisements and sale) act (Chapter 309) Singapore. Available: https://sso.agc.gov.sg/SL/TCASA1993-S7692014?DocDate $=20180131$ [Accessed 30 July 2019].

29 Oliveira da Silva AL, Bialous SA, Albertassi PGD, et al. The taste of smoke: tobacco industry strategies to prevent the prohibition of additives in tobacco products in Brazil. Tob Control 2019:28:e92-101.

30 BAT Uganda Ltd. Attorney General \& Center for Health, Human Rights and Development. Constitutional Court of Uganda, 2019. Available: https://www. tobaccocontrollaws.org/litigation/decisions/ug-20190528-bat-uganda-Itd-v.-attorneygen [Accessed 16 Aug 2019].

31 Joint FAO/WHO Expert Committee on Food Additives. Combined compendium of food additive specifications. volume 4: analytical methods, test procedures and laboratory solutions used by and referenced in the food additive specifications, 2006. Available: https://www.who.int/foodsafety/areas_work/chemical-risks/jecfa/en/ [Accessed 07 Mar 2019].

32 Smith RL, Waddell WJ, Cohen SM, et al. Gras 24: the 24th publication by the FemA expert panel presents safety and usage data on 236 new generally recognized as safe flavoring ingredients. Food Technol 2009;63:46-105.

33 Hall RL, Oser BL. Recent progress in the consideration of flavor ingredients under the food additives amendment. 3. GRAS substances. Food Technol 1965:151-97.

34 Mitchell A, Voon T. Regulating tobacco flavors: implications of the WTO law. Boston Univ Int Law J 2012;29:383-425 https://www.bu.edu/ilj/files/2014/05/MitchellVoonfinalpdf.pdf

35 WHO Study Group on Tobacco Product Regulation. Report on the scientific basis of tobacco product regulation: seventh report of a who Study Group, 2019. Available: https://apps.who.int/iris/bitstream/handle/10665/329445/9789241210249-eng.pdf [Accessed 28 Jan 2020].

36 Manning KC, Kelly KJ, Comello ML, et al. Flavoured cigarettes, sensation seeking and adolescents' perceptions of cigarette brands. Tob Control 2009;18:459-65.

37 McNeill A, Gravely S, Hitchman SC, et al. Tobacco packaging design for reducing tobacco use. Cochrane Database Syst Rev 2017;4:1465-858.

38 Lempert LK, Glantz S. Packaging colour research by tobacco companies: the pack as a product characteristic. Tob Control 2017;26:307-15.

39 Regulating Flavored Tobacco Products. Public health law center at Mitchell Hamline school of law, 2019. Available: https://www.publichealthlawcenter.org/sites/default/ files/resources/Regulating-Flavored-Tobacco-Products-2019-2.pdf [Accessed 28 Jan 2020].

40 Courtemanche CJ, Palmer MK, Pesko MF. Influence of the flavored cigarette ban on adolescent tobacco use. Am J Prev Med 2017;52:e139-46.

41 Delnevo CD, Hrywna M. Clove cigar sales following the US flavoured cigarette ban. Tob Control 2015;24:e246-50.

42 Villanti AC, Collins LK, Niaura RS, et al. Menthol cigarettes and the public health standard: a systematic review. BMC Public Health 2017;17:983-96. 